\title{
From bariatric to metabolic surgery in non-obese subjects: time for some caution
}

\author{
Da cirurgia bariátrica à cirurgia metabólica: tempo de \\ extremo cuidado em diabéticos não obesos
}

Mervyn Deitel'

\begin{abstract}
Severe obesity is associated with type 2 diabetes mellitus, and both resolve with weight loss after bariatric operations. Intestinal hormones have been identified which are stimulated by rapid nutrient delivery to the lower small bowel after certain weight-loss operations. These incretins stimulate secretion and hypertrophy of the pancreatic beta cells. Surgical procedures are now being performed to treat diabetes in adults of lesser weight, and the importance of ruling out latent autoimmune diabetes in the adult (a variety of type 1 ) is suggested, before experimenting with these procedures. Arq Bras Endocrinol Metab. 2009;53(2):246-251.

Keywords

Diabetes mellitus; obesity; bariatric surgery; insulin resistance; GLP-1; C-peptide; BMI
\end{abstract}

\section{RESUMO}

A obesidade grau III está francamente associada ao risco e à presença do diabetes tipo 2, sendo as duas condições passíveis de resolução com as cirurgias bariátricas. Hormônios gastrointestinais que formam eixo enteroinsular têm sido identificados, sendo mais intensa e rapidamente liberados após os procedimentos antiobesidade. Esses hormônios, entre os quais as incretinas, estimulam a secreção e a hipertrofia da células betapancreáticas. Novos procedimentos têm sido desenvolvidos para tratar o diabetes tipo 2 em adultos com obesidade em graus menos intensos. No entanto, é necessária a exclusão de pacientes com diabetes autoimune latente do adulto (LADA - uma variedade do diabetes tipo 1) antes da indicação de um procedimento cirúrgico. Arq Bras Endocrinol Metab. 2009;53(2):246-251.

Descritores

Diabetes melito; obesidade; cirurgia bariátrica; resistência à insulina; GLP-1; peptídeo C; BMI

\section{INTRODUCTION}

Curgery has developed as the most successful treatment $\checkmark$ for "morbid" obesity (i.e. obesity associated with serious, debilitating and progressive disease) $-\mathrm{BMI}>40$ $\mathrm{kg} / \mathrm{m}^{2}$ or $>35$ with co-morbidities (1). Bariatric operations were initially performed to decrease oral intake or to produce malabsorption, to decrease assimilation of energy (calories) and thereby result in loss of adipose tissue. It was soon realized that the metabolic co-morbidities of massive obesity resolved with weight loss - type 2 diabetes, dyslipidemia, hypertension, atherosclerosis and coronary artery disease, hepatic steatosis and even chronic inflammation. These co-morbidities made up a metabolic syndrome (2), and the most important disease of this syndrome is type 2 diabetes mellitus.

A discussion follows of the anthropologic development of insulin resistance and type 2 diabetes, the effects of the bariatric operations on type 2 diabetes, and some caution in the current trend to treat diabetes in normal-weight individuals by operations.

\section{DEVELOPMENTS OVER THE MILLENNIA}

Before the last ice age 10,000 years ago, our ancestors were hunter-gatherers. They hunted animals and also ate some roots and berries, consuming protein and 
some very complex carbohydrates (3-5). This coincides with a diet with a low glycemic index $(6,7)$. These meals were irregular and sometimes infrequent, and when there was a "kill", the entire clan would share the meal. Through natural selection, early man developed "thrifty" genes which conserved energy in times of famine (8).

In the Neolithic period, about 8,000 years ago, in the Fertile Crescent between the Mediterranean and Persian Gulf, farming started with indigenous wild grains (although the Crescent was eventually "overfarmed"). Agriculture likewise commenced in Turkey, Egypt, China and America - wheat, barley, oats, rye, rice, corn. The grains and further crops were ultimately refined. Regular and frequent meals of carbohydrate with a higher glycemic index became available, with frequent stimulation of insulin secretion by the pancreas (4). Insulin resistance developed with impaired glucose tolerance. This progressed over the centuries to the modern era, where convenient fast-foods containing particularly high levels of simple sugars, accompanied by a sedentary lifestyle, have resulted in the obesity epidemic. The metabolic syndrome, with insulin resistance, type 2 diabetes, and the related disorders are now prevalent. The prior "thrifty" genes now provide susceptibility to obesity.

We now have the increasing incidence of type 2 diabetes. The impaired glucose handling is associated with elevated plasma insulin and a down-regulation of insulin receptors (9). The high levels of circulating insulin inhibit lipolysis and promote lipogenesis.

\section{GLUCOSE PROCESSING FOLLOWING OPERATIONS FOR MORBID OBESITY}

Immediately following all types of bariatric operations, there is rapid improvement in glucose handling, before there is significant weight loss and often before the patient is even discharged from hospital $(10,11)$. After the old jejuno-ileal bypass (Figure 1), the oral glucose tolerance curve was markedly flattened - glucose bypassed its absorptive area in the intestine (12). Immediately after gastric restrictive (Figure 2) or gastric bypass (Figures 3, 4 and 5) operations with gastric pouch and stomal edema, the patient is able to consume only 575 \pm 146 calories per day at time of discharge from hospital (13-15); this leads to a rapid up-regulation of insulin receptors $(16,17)$ located on cell membranes in muscle and adipose tissue.

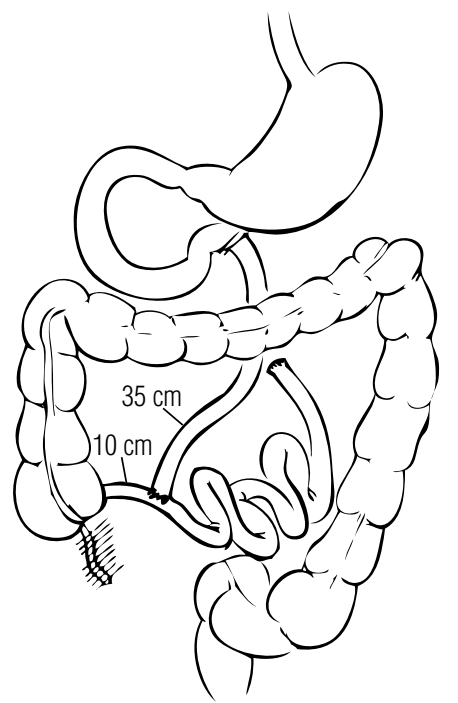

Figure 1. A jejuno-ileal bypass, providing rapid transit of food to the distal ileum and malabsorption.

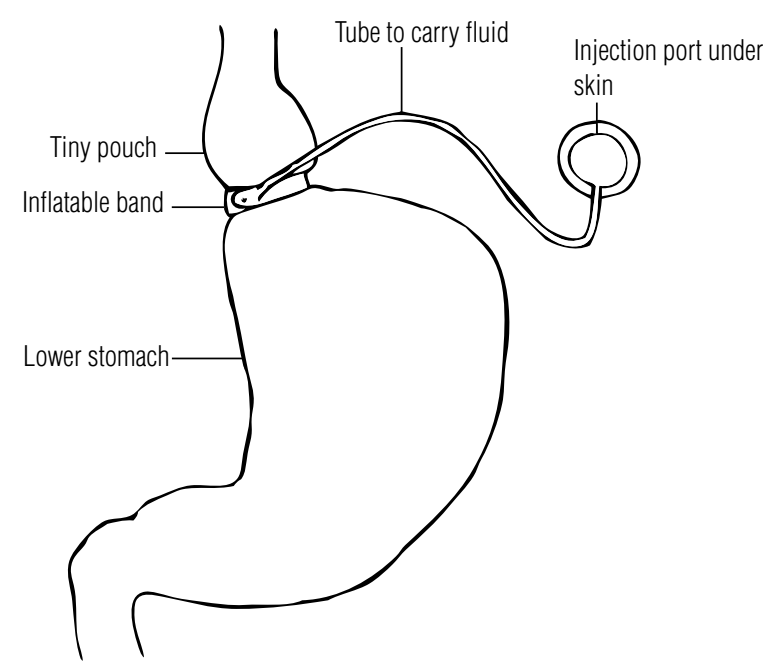

Figure 2. Adjustable gastric banding. A common gastric restrictive operation, limiting oral intake.

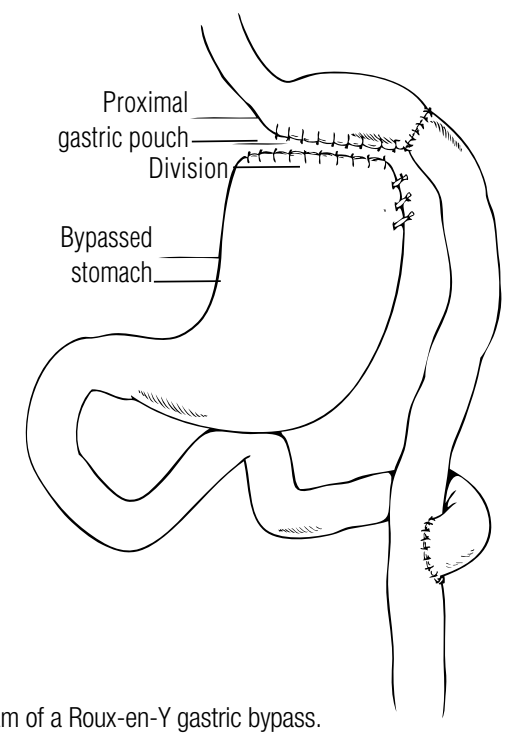

Figure 3. Diagram of a RouX-en-Y gastric bypass. 


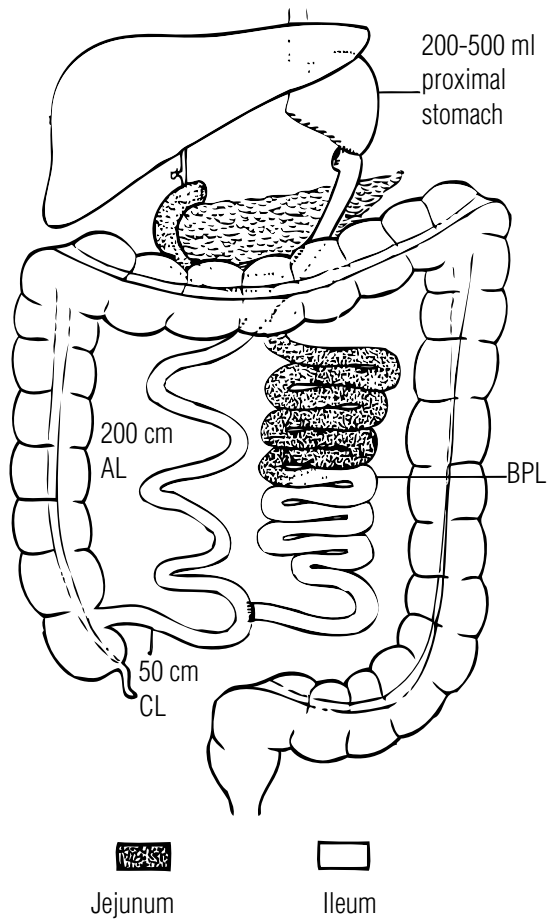

Figure 4. The malabsorptive biliopancreatic diversion operation results in rapid entrance of food into the hindgut.

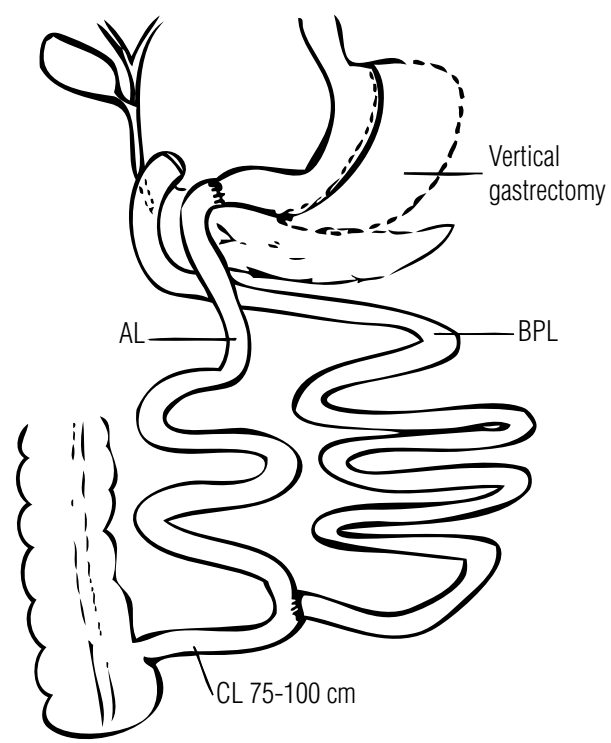

Figure 5. The duodenal switch operation also provides rapid exposure of the lower small bowel to nutrients.

Later, the improved glucose metabolism after gastric restrictive (18) and bypass (19) procedures is associated with the weight loss, and is greater after the bypass operations, which are followed by more rapid and greater decrease in fat mass (10).

After gastric bypasses, endocrine secretion from the bypassed foregut was originally postulated to be the cause of the improved glucose processing $(20,21)$. More recently, incretins (intestinal hormones that stimulate postprandial insulin secretion) secreted into the bloodstream because of expedited nutrient arrival in the distal small bowel, have been found to be elevated $(22,23)$. The most fascination has been with glucagonlike peptide-1 (GLP-1) secreted into the bloodstream by the L-cells of the hindgut (24-26). GLP-1(7-36) amide has been found to stimulate postprandial insulin secretion by the beta cells and to increase beta-cell mass (as well as delay emptying of the intact stomach) (22). GLP-1 and peptide YY have been associated with improvement of diabetes in those operations that bypass the proximal intestine $(27,28)$.

This has led to considerable GLP-1 interest, with a move by bariatric surgeons to treat diabetes in patients with lower BMIs (even below the obesity range) with a bariatric operation that includes bypass of proximal intestine -i.e. the gastric bypass, duodenal switch, and the original biliopancreatic diversion (29-31). The sleeve gastrectomy (Figure 6) has also been found to result in accelerated gastric emptying, with GLP-1 elevation (32). Additionally, those bariatric operations which remove the fundus of the stomach have the benefit of removing the main site of origen of the orexigenic hormone ghrelin (growth hormone releasing hormone) i.e. removing a site that causes the sensation of hunger in the empty stomach (33).

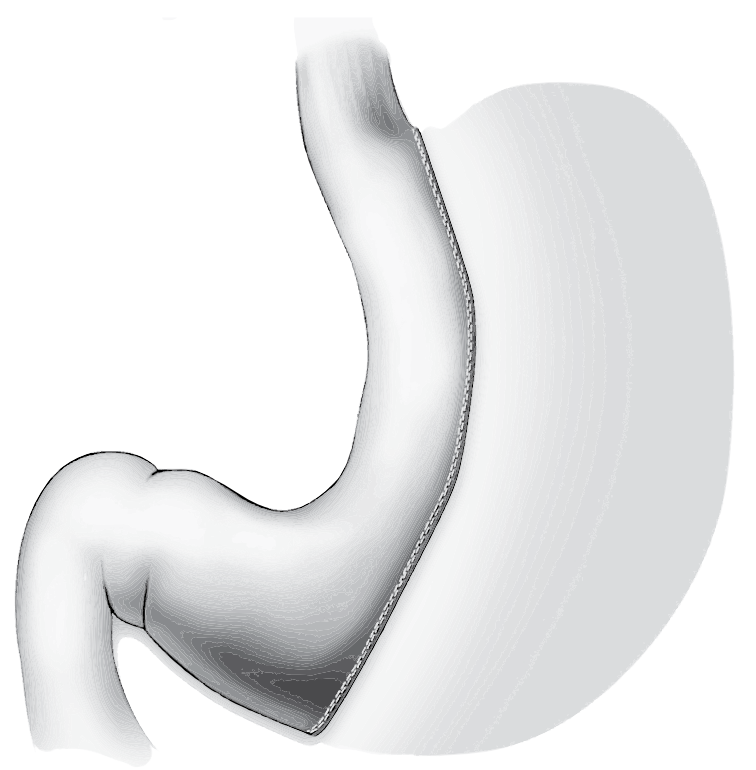

Figure 6. The sleeve gastrectomy alone (ie. the first part of the duodenal switch operation) has been found to have accelerated emptying of the lesser curvature gastric tube into the small bowel. 
This has led to current experimental operations for type 2 diabetes at lower BMIs, by ileal transposition (interposing a segment of the GLP-1-producing lower ileum into the proximal jejunum), to stimulate insulin secretion without weight loss $(34,35)$. Also, operations which empty food promptly into distal bowel and maintain the stomach, are being studied $(30,36)$.

\section{SLOW TYPE 1 DIABETES (LATENT AUTOIMMUNE DIABETES IN THE ADULT)}

A number of papers submitted to the Obesity Surgery journal regarding treatment of diabetes in adults with lower BMIs by gastric bypass, BPD or ileal interposition, had to be rejected because of inability to provide documentation. The patients had been assumed to have type 2 diabetes, but the presence instead of adult onset of type 1 diabetes had not been investigated.

Latent Autoimmune Diabetes in the Adult (LADA) has been reported to make up $10 \%$ of diabetics with onset at age 30 to 55 years. Like type 1 juvenile-onset diabetes, this is an autoimmune disorder, but the autoimmune destruction of the beta cells tends to be slower. It may have onset in adults who have normal weight, overweight or obesity, and tends to progress slowly (37-44). Diabetologists and endocrinologists frequently are not concerned whether this adult-onset diabetes is type 1 or 2 , because the treatment is generally the same, and the same complications may ultimately ensue (nephropathy, retinopathy, peripheral neuropathy, cardiovascular disease), although the microangiopathic complications are more typical in type 2 diabetes. The initial treatment for LADA type 1 diabetes has been antidiabetic drugs, which enhance the effect of the remaining endogenous insulin. However, as endogenous insulin decreases, the oral drugs eventually fail and LADA patients must ultimately be placed on exogenous insulin, unlike many type 2 diabetics.

LADA may be diagnosed by islet-cell antibodies and anti-glutamic acid decarboxylase antibodies. Plasma insulin levels in these individuals tend to be low (unlike often found in type 2 diabetics). Thus, the C-peptide level becomes very low, as the pancreas eventually has no beta-cell activity $(37,41,43)$.

Normally, when proinsulin is released from the pancreas into the bloodstream in response to a rise in serum glucose, the proinsulin is split into insulin and C-peptide (connecting peptide) - one C-peptide for each insulin molecule. Patients with LADA (slow type
1 diabetes), with autoimmune destruction of beta cells, are eventually unable to produce insulin, so that their C-peptide levels become very low (often $<0.25 \mathrm{ng} / \mathrm{ml}$, with no response to meal- or glucagon-stimulation).

In type 2 diabetics, C-peptide levels may be above normal or normal. With the insulin resistance and associated lipogenesis and lipotoxicity in type 2 diabetes, cells become "starved" for glucose, signaling a compensatory increase in insulin production; however, this can eventually lead to beta-cell apoptosis, unless treated with diet and hypoglycemic agents.

Early LADA may respond to stimulation by GLP-1. However, as beta cells are progressively and irreversably destroyed, these individuals must be placed on insulin and follow a strict oral intake regimen. If they undergo a gastric restrictive operation, which occasionally can have stomal edema, e.g. after NSAIDs or other irritating drugs, or more importantly, if they undergo a malabsorptive bariatric operation, in which hypertonic sugary liquids (45) or greasy meals precipitate rapid transit, it becomes difficult to standardize their insulin requirements. Thus, although LADA patients may have early satisfactory results after an "anti-diabetic" intestinal operation, the procedure can eventually lead to problems in tight diabetic control.

These "slow" type 1 diabetics do not have hyperinsulinemia and an associated metabolic syndrome. Their diabetic control is monitored by HbAlc determinations. Longstanding elevated plasma glucose in LADA (reflected by elevated HbAlc) will lead to diabetic complications. On the other hand, episodes of hypoglycemia from excess injected insulin can be problematic.

Thus, it is appropriate to differentiate between types 1 and 2 diabetes in the adult when bariatric surgery is being considered, particularly in patients whose BMI is below that of severe obesity. Published papers may have overlooked this feature, and/or have not provided adequate long-term follow-up regarding late insulin dependency $(29-31,35,36)$.

\section{GLP-1}

GLP-1 has an insulinotropic effect on the beta cells and its significance has even been compared to the discovery of insulin. However, in the situation of no endogenous insulin, diabetes is certainly present, whereas in the situation of no GLP-1, diabetes does not seem to occur. In patients with marked Crohn's disease and major resections when I worked under Dr. Leon Ginzburg in New York, 
and when I followed my own regional enteritis patients and bowel resections from the 1960s to 1990s, extensive ileo-colic (hindgut) resections were not followed by diabetes. Also, when I locally pioneered intravenous hyperalimentation (TPN) and many patients were referred with massive small bowel and right colon resections due to mesenteric vascular occlusion or antithrombin III deficiency, the development of diabetes postoperatively was not a feature. This requires future investigation.

\section{GLP-1 MIMETIC}

The GLP-1 mimetic, exenatide, has been synthesized (Byetta $^{\circledR}$, Amlyn Pharmaceuticals and Lilly, injected as $10 \mu \mathrm{g}$ subcutaneously twice daily) $(46,47)$. In type 2 diabetes with a lower BMI, if a bariatric-type operation is being considered, the GLP-1 mimetic may be tried first (with surveillance), as a test or as treatment to produce a GLP-1 effect on the pancreas, to determine the effect $(26,28)$.

As another tactic, the enzyme dipeptyl peptidase- 4 (DPP-4) rapidly inactivates GLP-1; DPP-4 inhibitors (Sitagliptin Vildagliptin), taken orally, are now available (47).

Disclosure: No potential conflict of interest relevant to this article was reported.

\section{REFERENCES}

1. Deitel M, Shahi B. Morbid obesity: selection of patients for surgery. J Am Coll Nutr. 1992;11(4):457-62.

2. Reaven GM.The individual components of the metabolic sysndrome: is there a raison d'etre? J Am Coll Nutr. 2007: 26(3):191-5.

3. Deitel M. The obesity epidemic (editorial). Obes Surg. 2006; 16(4):377-8.

4. Eades MR, Eades MD. Protein Power. New York: Bantam, 1996.

5. Brody H. The other side of Eden: hunter-gatherers, farmers and the shaping of the world. UK: Faber \& Faber, 2002.

6. Jenkins DJ, Wolever TM, Taylor RH, Barker H, Fielden $\mathrm{H}$, Baldwin JM, et al. Glycemic index of foods: a physiological basis for carbohydrate exchange. Am J Clin Nutr. 1981;34(3):362-6.

7. Jenkins DJ, Kendall CW, Augustin LS, Franceschi S, Hamidi M, Jenkins AL, Axelsen M. Glycemic index: overview of implications in health and disease. Am J Clin Nutr. 2002; 76(1):266S-73S.

8. Baier LJ, Hanson RL. Genetic studies of the etiology of type 2 diabetes in Pima Indians. Diabetes. 2004;3(5):1181-6.

9. Sanderson I, Deitel M. Insulin response in patients receiving concentrated infusions of glucose and casein hydrolysate for complete parenteral nutrition. Ann Surg. 1974;179(4)387-94.

10. Gumbs AA, Modlin AM, Ballantyne GH. Changes in insulin resistance following bariatric surgery: role of caloric restriction and weight loss. Obes Surg. 2005;15(4):462-73.

11. Wickremesekera K, Millor G, Naotunne TD, Knowles G, Stubbs RS. Loss of insulin resistance after Roux-en-Y gastric bypass surgery: a time course study. Obes Surg. 2005;15(4):474-81.
12. Sanderson I, Deitel M, Bojm MA. The handling of glucose and insulin response before and after weight loss with jejuno-ileal bypass: a preliminary report. JPEN. 1983;7(3):274-6.

13. Deitel M, Sidhu PS, Stone E. Effect of vertical banded gastroplasty on diabetes in the morbidly obese. Obes Surg. 1991;1(1):113-4 (abstr).

14. Keith $\mathrm{SH}$, Mason EE, Scott DH, Ginsberg BH. Serum insulin and glucose levels, and insulin binding kinectics, in morbid and super obese patients undergoing vertical banded gastroplasty. Obes Surg. 1991:1(1):112 (abstr).

15. Smith SG, Edwards CB, Goodman GM. Changes in diabetic management after Roux-en-Y gastric bypass. Obes Surg. 1996; 6(4):345-8.

16. Halverson JD, Kramer J, Cave A, Permutt A, Santiago J. Altered glucose tolerance, insulin response, and insulin sensitivity after massive weight reduction subsequent to gastric bypass. Surgery. 1982;92(2):235-40.

17. Deitel M. The early effect of bariatric operations on diabetes (commentary). Obes Surg. 2002;12(3):349.

18. Dixon JB, Dixon AF, O'Brien PE. Improvement in insulin sensitivity and beta cell function (HOMA) with weight loss in the severely obese. Homeostatic model assessment. Diab Med. 2003;20(2):127-34.

19. Burstein R, Epstein Y, Charuzi I, Suessholz A, Karnieli E, Shapiro $Y$. Glucose utilization in morbidly obese subjects before and after weight loss by gastric bypass operation. Int $\mathrm{J}$ Obes. 1995;19(8):558-61.

20. Pories WJ. Why does the gastric bypass control type 2 diabetes mellitus? Obes Surg. 1992; 2(4):303-13.

21. Rubino F, Forgione $A$, Cummings $D E$, Vix $M$, Gnuli $D$, Mingrone $G$, et al. The mechanism of diabetes control after gastrointestinal bypass reveals a role of the proximal small intestine in the pathophysiology of type 2 diabetes. Ann Surg. 2006;244(5):741-9.

22. Lamounier RN, Pareja JC, Tambascia MA, Geloneze B. Incretins: clinical pathophysiology and bariatric surgery - correlating the entero-endocrine system and a potentially anti-dysmetabolic procedure. Obes Surg. 2007;17(5):569-76.

23. de Carvalho CP, Marin DM, de Souza AL, Pareja JC, Chaim EA, de Barros, et al. GLP-1 and adiponectin: effect of weight loss after dietary restriction and gastric bypass in morbidly obese patients with normal and abnormal glucose metabolism. Ob Surg. 2009; 19:313-20.

24. Näslund E, Backman L, Holst JJ, Theodorsson E, Hellström PM. Importance of small bowel peptides for the improved glucose metabolism 20 years after jejunoileal bypass for obesity. Obes Surg. 1998; 8(3):253-60.

25. Mason EE. The mechanisms of surgical treatment of type 2 diabetes (editorial). Obes Surg. 2005;15(4):459-61.

26. Mason EE. Gastric emptying controls type 2 diabetes mellitus (editorial). Obes Surg. 2007; 17(7):853-5.

27. Valverde I, Puente J, Martin-Duce A, Molina L, Lozano O, Sancho $V$, et al. Changes in glucagon-like peptide-1 (GLP-1) secretion after biliopancreatic diversion or vertical banded gastroplasty in obese subjects. Obes Surg. 2005; 15(3):387-97.

28. Mason EE. Gila Monster's guide to surgery for obesity and diabetes. J Am Coll Surg. 2008;206(2):357-60.

29. Livingston EH. Lowering the bariatric surgery minimum body mass index threshold. Arch Surg. 2008;143(7):708-10.

30. Cohen RV, Schiavon GA, Pinheiro JS, Correa JL, Rubino F. Duodenal-jejunal bypass for the treatment of type 2 diabetes with BMI 22$24 \mathrm{~kg} / \mathrm{m}^{2}$ a report of 2 cases. Surg Obes Relat Dis. 2007; 3(2):195-7.

31. Scopinaro N, Papadia F, Marinari G, Camerini G, Adami G. Longterm control of type 2 diabetes mellitus and the other major components of the metabolic syndrome after biliopancreatic diversion in patients with $\mathrm{BMI}<35 \mathrm{~kg} / \mathrm{m}^{2}$. Obes Surg. 2007;17(2):185-92. 
32. Melissas J, Daskalakis M, Koukouraki S, Askoxylakis I, Metaxari $M$, Dimitriadis $E$, et al. Sleeve gastrectomy - a food-limiting operation. Obes Surg. 2008;18(7):1251-6.

33. Frühbeck G, Diez-Cabellero A, Gil MJ, Montero I, Gomez-Ambrosi, Salvador J, Cienfuegos JA. The increase in plasma ghrelin concentrations following bariatric surgery depends on the functional integrity of the fundus. Obes Surg. 2004;14(5):606-12.

34. Mason EE. Ilial (Ileal) transposition and enteroglucagon/GLP-1 in obesity (and diabetic?) surgery. Obes Surg. 1999; 9(3):223-8.

35. DePaula AL, Macedo CA, Rassi N, Machado CA, Schraibman, Silva LQ, Halpern A. Laparoscopic treatment of type 2 diabetes mellitus for patients with body mass index less than 35 . Surg Endosc. 2008;22(3):706-16.

36. Ramos AC, Galvao MP, de Souza YM, Galvao M, Murakami AH, Silva $A C$, et al. Laparoscopic duodenal-jejunal exclusion in the treatment of type 2 diabetes mellitus in patients with $\mathrm{BMI}>30 \mathrm{~kg} /$ $\mathrm{m}^{2}$ (LBMI). Obes Surg. 2008; Nov 6 (Epub ahead of print).

37. Zimmet P, Turner R, McCarty D, Rowley M, MacKay I. Crucial points at diagnosis. Type 2 diabetes or slow type 1 diabetes. Diab Care. 1999; 22(Suppl 2):B59-64.

38. Seisser J. Latent (slowly progressing) autoimmune diabetes in adults. Curr Diab Rep. 2008;8(2):94-100.

39. Brophy S, Yderstraede K, Mauricio D, Hunter S, Hawa M, Pozzilli $\mathrm{P}$, et al.Time to insulin initiation cannot be used in defining latent autoimmune diabetes in adults. Diab Care. 2008;31(3):439-41.
40. Rosario PW, Reis JS, Fagundes TA, Calsolari MR, Amim R, Silva Sc Purisch S. Latent autoimmune diabetes in adults (LADA): usefulness of anti-GAD antibody titers and benefit of early insulinization. Arq Bras Endocrinol Metabol. 2007;51(1):52-8.

41. Landin-Olsson M. Latent autoimmune diabetes in adults. Ann NY Acad Sci. 2002;958:112-6.

42. Davies H, Mannan S, Brophy S, Williams R. Routine glutamic acid decarboxylase autoantibody (GADA) testing: patients' perspective. Fam Pract. 2008;25(3):176-80.

43. Murao S, Kondo S, Ohashi J, Fujii Y, Shimizu I, Fujiyama M, et al. Anti-thyroid peroxidase antibody, IA-2 antibody, and fasting Cpeptide levels predict beta cell failure in patients with latent autoimmune diabetes in adults (LADA) - 5-year follow-up of the Ehime study. Diab Res Clin Pract. 2008;80(1):114-21.

44. Szelachowska M. LADA - latent autoimmune diabetes in adults. Endokrynol Pol. 2007;58(3):246-51.

45. Deitel M. The change in the dumping syndrome concept (commentary). Obes Surg. 2008;18(12):1622-4.

46. Drucker DJ, Nauck MA. The incretin system: glucagon-like-peptide-1 receptor agonists and dipeptyl peptidase-4 inhibitor in type 2 diabetes. Lancet. 2006;368(9548):1696-705.

47. Madsbad S, Krarup T, Deacon CF, Holst JJ. Glucagon-like peptide receptor agonists and dipeptyl peptidase- 4 inhibitors in the treatment of diabetes: a review of clinical trials. Curr Opin Clin Nutr Metab Care. 2008;11(4):491-9. 